\title{
Influence of Undisturbed Ground Temperature and Geothermal Gradient on the Sizing of Borehole Heat Exchangers
}

\author{
Tomislav Kurevija ${ }^{1, *}$, Domagoj Vulin ${ }^{1}$, Vedrana Krapec ${ }^{1}$ \\ ${ }^{1}$ Faculty of Mining, Geology and Petroleum Engineering, University of Zagreb, Zagreb, Croatia \\ *Corresponding author. Tel: +385 1 5535843, Fax: +385 1 4836074, E-mail: tkurevi@rgn.hr
}

\begin{abstract}
Undisturbed ground temperature is one of the most crucial thermogeological parameters needed for shallow geothermal resources assessment. Energy considered to be geothermal is energy stored in the ground at depths where solar radiation has no effect. At depth where undisturbed ground temperature occurs there is no influence of seasonal variations in air temperature from surface. Exact temperature value, and depth where it occurs, is functionally dependent on surface climate parameters and thermogeologic properties of ground. After abovementioned depth, increase of ground temperature is solely dependent on geothermal gradient. Accurately determined values of undisturbed ground temperature, and depth of occurrence, are beneficial for proper sizing of borehole heat exchangers and ground source heat pump system as a whole.

On practical example of building being heated and cooled with shallow geothermal resource, via heat pump system, influence of undisturbed ground temperature and geothermal gradient on size of borehole heat exchanger is going to be presented. Sizing of borehole heat exchanger was calculated with commercial software Ground Loop Designer (GLD), which uses modified line source and cylinder source solutions of heat conduction in solids.
\end{abstract}

Keywords: Borehole heat exchanger, Shallow geothermal energy, Geothermal heat pump, Undisturbed ground temperature, Geothermal gradient

\section{Introduction}

Today most of the commercially available simulation software packages that are used for sizing of geothermal heat pumps systems with borehole heat exchangers apply one of two (or both) theoretical heat transfer models. The first model is based on the cylindrical source model and allows for quick but accurate length or temperature calculations based on limited data input. The second model is based on a simple line source theory, but is more detailed in its ability to generate monthly temperature profiles over time given monthly loads and peak data. Although the solutions of the two models do not always agree, and strongly differ on valuation of thermal interferences effect, they do give the engineer more information on which to base a final borehole heat exchanger system design.

The vertical bore length equations used in the first model, also known as ASHRAE/Kavanaugh model, are based upon the solution for heat transfer from a cylinder buried in the earth. The method was developed and tested by Carslaw and Jaeger (1946). The solution gives a temperature difference between the outer cylindrical surface and the undisturbed ground temperature. Ingersoll suggested using the equation and its solution for the sizing of borehole heat exchangers in cases where the extraction or rejection of heat occurs in periods of less than six hours, where the simple line source model fails (Ingersoll, 1954). The model was further improved by solution of Kavanaugh and Deerman (1991) who arranged the methods of Ingersoll to account for U-pipe layout and hourly heat variations. For the first model, the most complete description of method and input data can be found in reference Kavanaugh and Rafferty (1997).

The second model, also known as Lund/Swedish model, is based on the solution to the solely heat conduction in a homogenous medium, which was solved by approximating the borehole as a finite line sink using superposition principle (Eskilson, 1987). The steady state solution 
relates to the case where heat is extracted continuously from the borehole without ever exhausting the heat source, making it a fully renewable source of energy. The difference between the second model and the first one is that with the second model it is possible to calculate the evolution of the borehole wall temperature over time when a constant heat rate is extracted from the borehole. It makes use of a dimensionless $g$-function method to model the temperature variations, taking into account the ratio of the borehole radius and length and the physical layout of the bore field.

However, both of those models are not particularly considering geothermal gradient in their analysis, claiming that impact of geothermal gradient on overall borehole length needed for heat transfer is rather small and therefore should be neglected. This paper will discuss difference in results of borehole grid array design, obtained by applying Eskilson/Lund model in simulation process of geothermal heat pump system. Model will include two separate ground temperature inputs: one with entering solely undisturbed ground temperature at the site, and the other by entering effective ground temperature with applied geothermal gradient.

\section{Influence of Undisturbed Ground Temperature and Geothermal Gradient}

Ground surface is exposed to the solar radiation effect to the certain depth. The intensity of solar radiation is different because of geographic location, morphology and plant diversity. Ground temperature is generally a function of solar heat transferred by radiation, convection and conduction. Undisturbed ground temperature could be considered to occur at depth where annual ground temperature amplitude becomes as low as $0,1^{\circ} \mathrm{C}$. Undisturbed ground temperature in fact represents temperature at the depth where exists equilibrium from solar radiation from surface and geothermal heat flow from Earth's crust.

Eskilson (1987), states that only an average undisturbed ground temperature is of importance for the heat extraction analysis while geothermal gradient and surface variations are neglected. This average temperature is normally with good accuracy equal to the undisturbed ground temperature at the mid-depth of the borehole. Experimentally, it is determined by circulating the heat carrier fluid without heat extraction or injection (prior Thermal Response Test). The circulating fluid assumes after a short transient period a steady temperature. Heat is then flowing to the lower half of the borehole from the surroundings, which have a temperature above average undisturbed ground temperature, and the same amount of heat is flowing from the borehole to the somewhat colder surroundings in the upper half. Ekilson (1987) also shown that the errors in heat extraction performance, when the simplified initial and boundary conditions are used (average undisturbed ground temperature on mid-depth of bore) instead of more precise ones which include geothermal gradient and temperature variations at surface, are characteristically less than $1 \%$. This analysis was carried out with geothermal gradient of $0,0162^{\circ} \mathrm{C} / \mathrm{m}$ which is common value for northern regions of Europe. Question emerges what would be effect of geothermal gradient on heat transfer in areas where this value is significantly higher. As shown on Figure 1, northern part of the Republic of Croatia posses much higher geothermal gradients in range between $0,04-0,07{ }^{\circ} \mathrm{C} / \mathrm{m}$. For example, capital city Zagreb, which is located in northwest part of Croatia has average gradient of $0,05^{\circ} \mathrm{C} / \mathrm{m}$.

To also include surface temperature variations in analysis of determining average ground temperature through the borehole and simulate heat transfer between geothermal heat pump systems it is necessary to determine real depth where undisturbed ground temperature occurred. Long-term temperature measurements from $2 \mathrm{~cm}$ up to $100 \mathrm{~cm}$ are conducted on the points of observation by the Meteorological and Hydrological Service of the Republic of 
Croatia (DHMZ). Maximum yearly amplitudes $\left(25,1^{\circ} \mathrm{C}\right)$ in the ground temperature were observed at the depth of $2 \mathrm{~cm}$ in city of Zagreb. Annual amplitudes are decreasing to $15,1^{\circ} \mathrm{C}$ at $100 \mathrm{~cm}$ depth. By analyzing damping of temperature amplitudes, analytical solution by means of extrapolation of a ground temperature versus depth is possible, as published in previous research paper (Kurevija 2010.). If there are no measured data, yearly temperature oscillation at some depth can be estimated with sinusoidal function solving the differential equation as described by Hillel (1982).

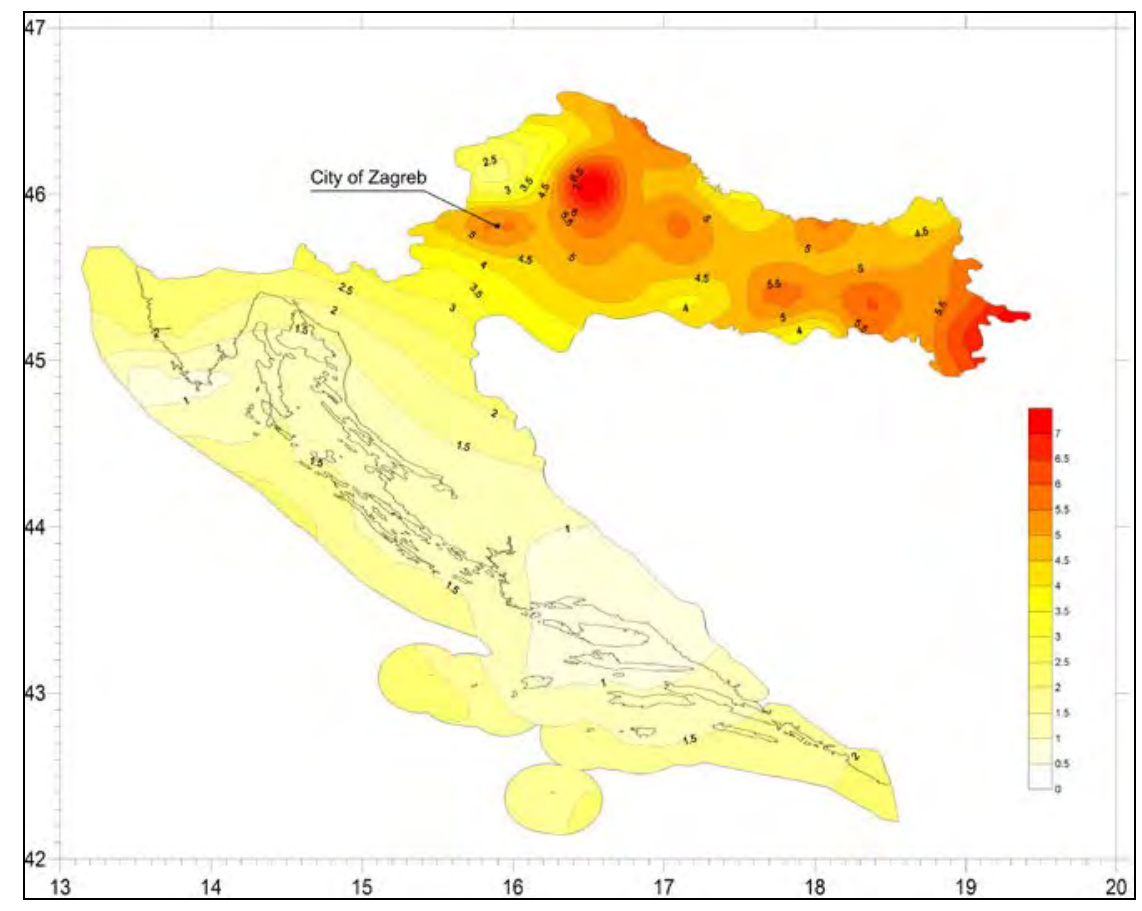

Fig. 1. Geothermal gradients in the Republic of Croatia

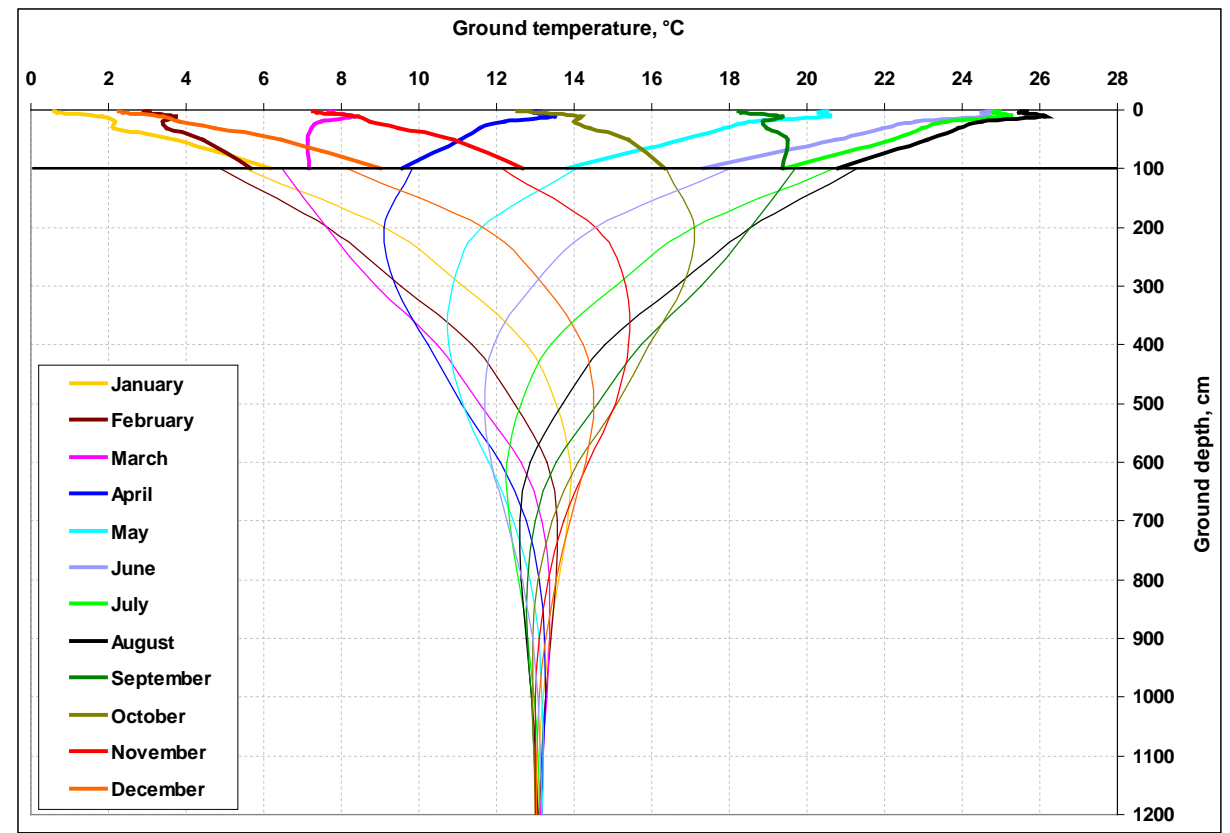

Fig.2. Measured average monthly ground temperatures up to $100 \mathrm{~cm}$ and calculated monthly ground temperature oscillations (100-1200 cm) for a meteo station Zagreb-Maksimir (Kurevija, 2010) 
By solving the sinusoidal temperature amplitude damping function it can be perceived from Fig.2. that for depth of $1200 \mathrm{~cm}$ ground temperature amplitude amounts $0,1^{\circ} \mathrm{C}$, and undisturbed ground temperature equals $13,1^{\circ} \mathrm{C}$. This value is one of the most important parameters in modeling of borehole heat exchanger.

\section{Analysis of Geothermal Heat Pump with Borehole Heat Exchanger Field}

After determining undisturbed ground temperature and geothermal gradient in Zagreb location, analysis of ground heat exchanger will be carried out to determine impact of those two parameters. As an example, building with total area of $2500 \mathrm{~m}^{2}$ and completely heated and cooled with shallow geothermal resource will be discussed. Numerical computation and sizing of borehole heat exchanger will be done with commercially available software Ground Loop Designer (GLD) which uses both heat transfer models described in introduction chapter. Second model will be applied (simplified line source heat transfer theory - Swedish/Lund method) because it gives more detailed evolution of the borehole wall and carrier fluid temperatures over long-term period.

Analysis will be based on fixed number of bores in borehole heat exchanger field. Two boreholes array grid will be discussed to determine effect of thermal interferences over longterm period of utilization, one rectangular shaped and compactly arranged in form $5 \times 4$, which is presumed to have significant borehole thermal interference effect on loop sizing, and one rectangular shaped in form of $10 x 2$ which is presume to have smaller interferences. Both grids will be simulated in two modes: first one by importing only undisturbed ground temperature (if there is lack of data from circulating carrier fluid through bores prior Thermal Response Test - this is usually done for first approximation in pre-feasibility studies) and second one by importing effective ground temperature (mean ground temperature through the bore depth calculated by including surface variations in first few meters of soil and geothermal gradient which describes temperature rise versus depth). Table 1 shows input data from building annual energy consumption. This was simulated using building energy balance software $K I$ Expert which incorporates Croatian directives regarding rational use of energy in buildings and prescribes allowable thermal conductivity factors.

Table 1. Building energy balance

\begin{tabular}{|c|c|c|}
\hline Month & Heating & Cooling \\
\hline Januarv & 40633 & 195 \\
\hline February & 25544 & 311 \\
\hline March & 13288 & 764 \\
\hline April & 4003 & 2499 \\
\hline May & 418 & 6403 \\
\hline June & 14 & 10190 \\
\hline July & 0 & 13170 \\
\hline August & 3 & 10261 \\
\hline September & 398 & 4392 \\
\hline October & 6343 & 1284 \\
\hline November & 21831 & 341 \\
\hline December & 37859 & 289 \\
\hline Total, kWh & 150355 & 50096 \\
\hline Heating/Cooling ratio & \multicolumn{2}{|c|}{3,00} \\
\hline Peak load 8 hours, kW & 99,2 & 95,8 \\
\hline Annual full load hours & 1516 & 523 \\
\hline
\end{tabular}


From Table 1 it can be seen that the ratio between energy used during heating season and energy used during cooling season is 3,0. This indicates that more heat would be extracted to the ground than it would be rejected to it (in cooling mode total rejected heat to the ground is the sum of heat rejected from the building and the heat of compression from heat pump) which doubtlessly would cause some cooling of the ground in long-term period of utilization. Borehole input parameters and thermogeological characteristics of the ground at the location can be seen from Table 2. Value of ground thermal conductivity was taken from in-situ measurements conducted on 100m bore (Soldo 2010). Table 3. shows example of designed input parameters for the heat pump system (Waterfurnace EKW130 was used for purpose of this analysis). Building is presumed to have floor heating system with leaving load temperature (LLT) of $40,8^{\circ} \mathrm{C}$ with entering load temperature (ELT) to the heat pump of $37,8^{\circ} \mathrm{C}$. Loop side is set with entering source temperature (EST) of $0^{\circ} \mathrm{C}$ and leaving source temperature (LST) of $-2,3^{\circ} \mathrm{C}$.

Table 2. Borehole heat exchanger and thermogeological ground parameters at the site

\begin{tabular}{|c|c|}
\hline Loop solution properties & $\begin{array}{l}\text {-Water } 76,5 \% \text { - Propylene glycol } 23,5 \% \text { mixture; } \\
\text {-Freezing point: }-9,4^{\circ} \mathrm{C} \\
\text {-Specific heat capacity: } 3,992 \mathrm{~kJ} / \mathrm{kg}^{\circ} \mathrm{C} \text {; } \\
\text {-Density } 1024,5 \mathrm{~kg} / \mathrm{m}^{3}\end{array}$ \\
\hline Polyethylene single U-pipe parameters & $\begin{array}{l}\text {-Pipe size } 1 "(27,41 \mathrm{~mm} \mathrm{ID} / 33,40 \mathrm{~mm} \text { OD); } \\
\text {-Pipe type SDR11; } \\
\text {-Thermal resistance: } 0,060 \mathrm{~m}{ }^{\circ} \mathrm{C} / \mathrm{W} \text {; } \\
\text {-Average radial pipe placement inside bore }\end{array}$ \\
\hline Borehole parameters & $\begin{array}{l}\text {-Diameter } 130 \mathrm{~mm} \text {; } \\
\text {-Grout thermal conductivity: 2,13 } \mathrm{W} / \mathrm{m}^{\circ} \mathrm{C} \text {; } \\
\text {-Borehole eq. thermal resistance: } 0,121 \mathrm{~m}{ }^{\circ} \mathrm{C} / \mathrm{W} \\
\text {-Separation distance in grid array: } 6,0 \mathrm{~m}\end{array}$ \\
\hline Ground properties & $\begin{array}{l}\text {-Lithology: mostly brown wet clay and unconsolidated } \\
\text { coarse sand with thin layers of gravel and marl } \\
\text {-Mean volume-specific heat capacity: } 2,77 \mathrm{MJ} / \mathrm{m}^{3}{ }^{\circ} \mathrm{C} \\
\text {-Undisturbed ground temperature: } 13,1^{\circ} \mathrm{C} \\
\text {-Mean thermal conductivity: } 1,70 \mathrm{~W} / \mathrm{m}^{\circ} \mathrm{C} \\
\text {-Mean thermal diffusivity: } 0,053 \mathrm{~m}^{2} / \text { day }\end{array}$ \\
\hline
\end{tabular}

Table 3. Example of heat pump system designed input parameters used in ground loop simulation for grid array $5 \times 4$ with geothermal gradient included in analysis

\begin{tabular}{lrr}
\hline Grid array 5x4 with included geothermal gradient & $\begin{array}{r}\text { Heating } \\
\text { Cooling }\end{array}$ \\
\hline Source side fluid temperatures, ${ }^{\circ} \mathrm{C}$ & $\begin{array}{r}0 /-2,3 \\
\text { (EST/LST) }\end{array}$ & $\begin{array}{r}23,6 / 27,4 \\
(\mathrm{EST} / \mathrm{LST})\end{array}$ \\
\hline Load side fluid temperatures, ${ }^{\circ} \mathrm{C}$ & $\begin{array}{r}37,8 / 40,8 \\
\text { (ELT/LLT) }\end{array}$ & $\begin{array}{r}12,0 / 8,5 \\
(\mathrm{ELT} / \mathrm{LLT})\end{array}$ \\
\hline Total unit capacity, $\mathrm{kW}$ & 99,2 & 114,6 \\
\hline System peak load, $\mathrm{kW}$ & 99,2 & 95,8 \\
\hline Compressor peak demand, $\mathrm{kW}$ & 28,3 & 18,8 \\
\hline Heat pump COP, $\mathrm{kW} / \mathrm{kW}$ & 3,5 & 5,1 \\
\hline Heat extracted/rejected from/to ground & 70,9 & 114,6 \\
\hline Heat pump partial load factor & 1,00 & 0,85 \\
\hline
\end{tabular}


Investigations carried out in relevant literature (Kavanaugh 1984, Eskilson 1987) suggest that geothermal heat pump systems should be sized for at least 30 years period of operation to minimize thermal interferences effects and account sub-cooling of the ground. Principle of multi-year sizing is not to allow minimum temperature of the carrier fluid during peak-load conditions to approach its freezing point during that time and to assure that average fluid temperature of the solution inside the loop be near designed $0^{\circ} \mathrm{C}$ even after 30 years of operation. If the geothermal system is designed just for 1 year operation, result would be rather small and 'economic' loop size but after multi year of operation loop solution temperature would significantly drop, due to thermal interferences and sub-cooling of the ground, resulting in that way in very inefficient and troublesome system.

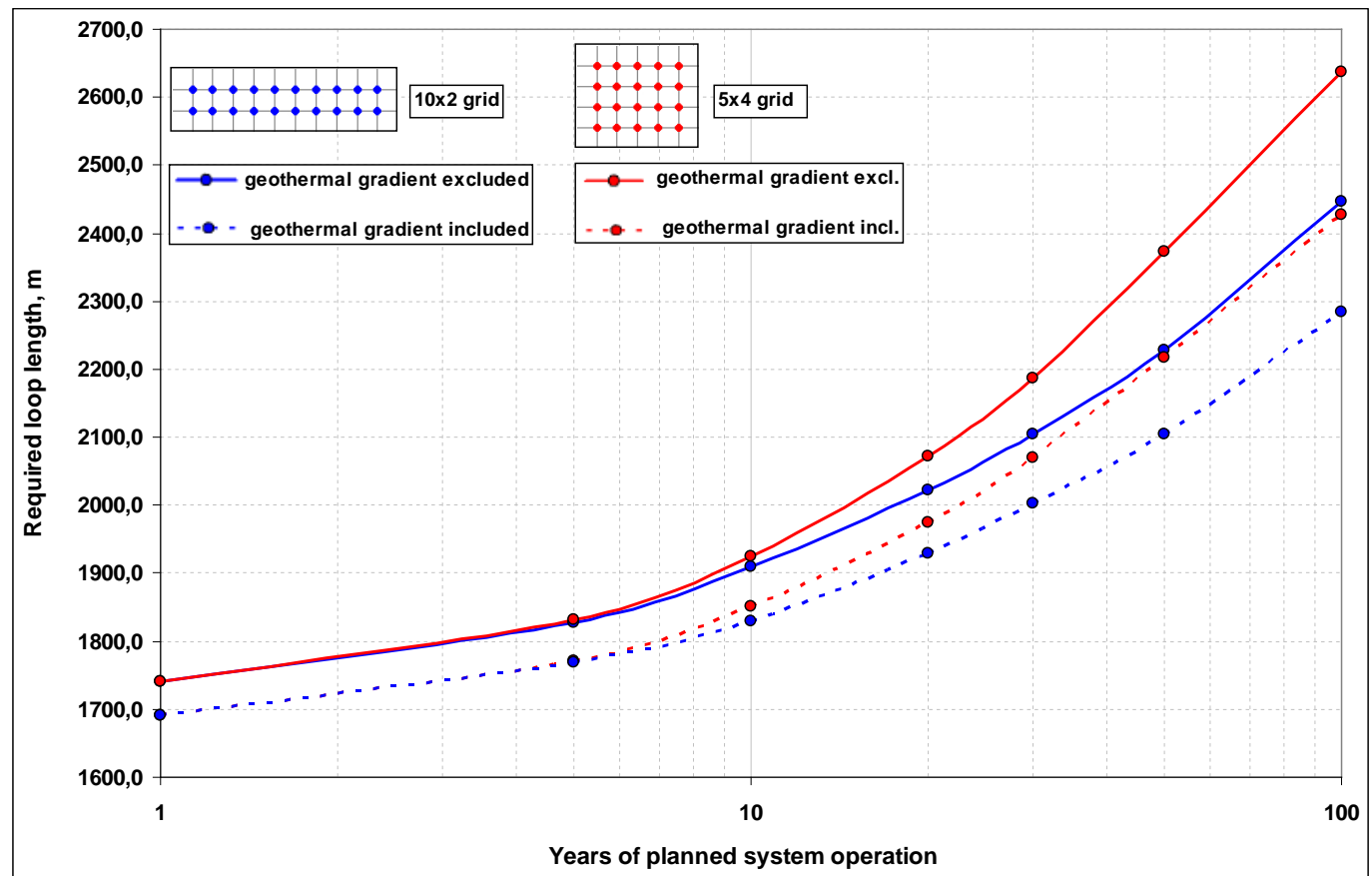

Fig.3. Results of sizing ground loop according to years of planned system operation and various array grids with input data presented in Tables 1,2 and 3 with borehole spacing distance of 6,0m

On Fig.4. results of ground loop simulation are presented. As mentioned, ground loop was simulated for two different grids, compact rectangular $5 \times 4$ grid and rectangular 10x2 grid. For both grids variations where calculated inserting in model firstly undisturbed ground temperature of $13,1^{\circ} \mathrm{C}$ for Zagreb location and then secondly effective ground temperature, which was influenced by geothermal gradient. Variations for different borehole separation distances were introduced to evaluate effect of thermal distances. It can be seen that for low separation distances (below 6,0 m) loop size drastically arises to compensate effect of thermal interferences of an adjacent bores. Also, it can be perceived that geothermal gradient, if introduced in effective ground temperature calculation, significantly influences loop size. For instance, if 5x4 array grid with bores separation distance of $6,0 \mathrm{~m}$ is observed, as shown in results from Table 4, it can be seen that analysis which included geothermal gradient in effective ground temperature calculation has 5,3\% reduction in loop length, as oppose to analysis which included only undisturbed ground temperature. 


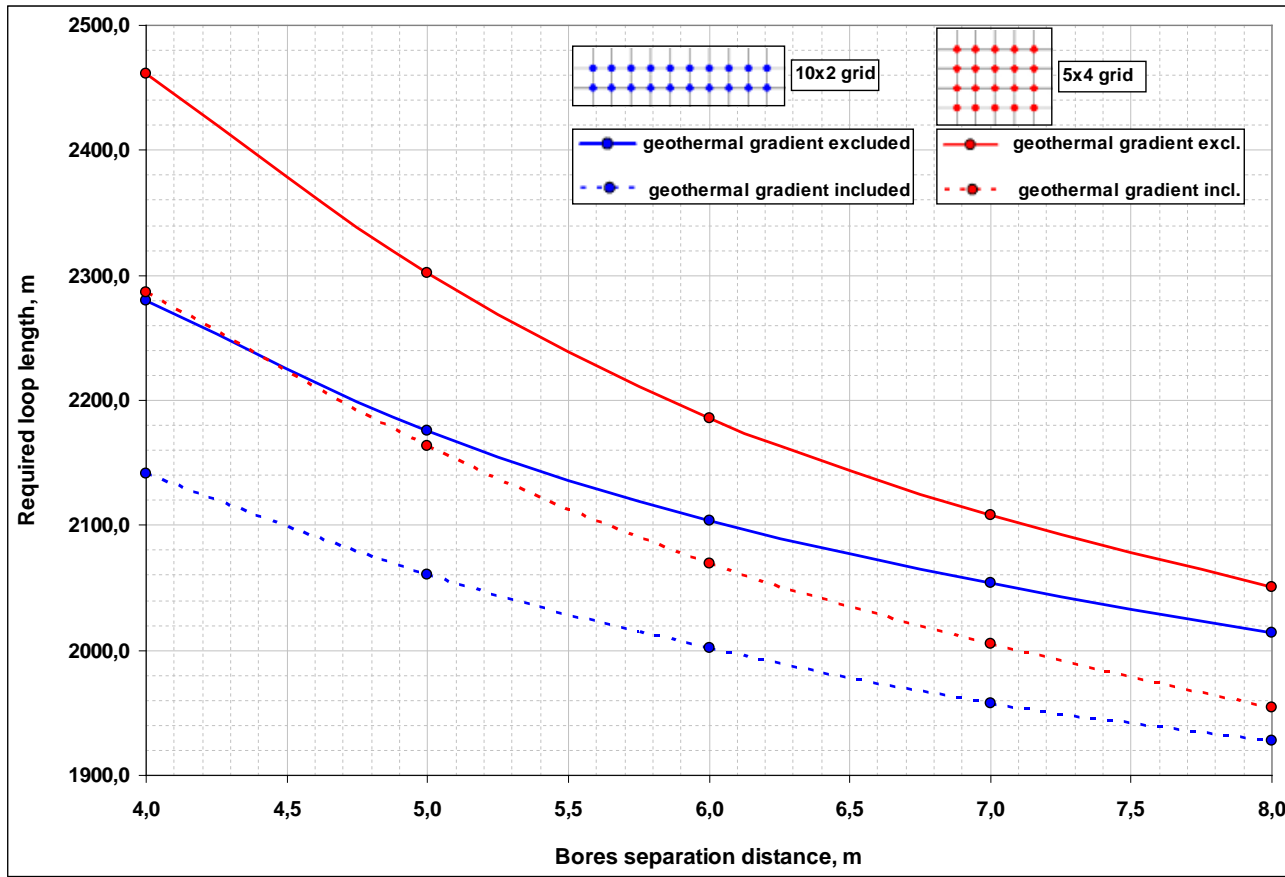

Fig.4. Results of sizing ground loop according to different borehole separation distances and various array grids with input data presented in Tables 1,2 and 3 for 30 years of operation

Table 4. Results of sizing borehole ground loop with calculated changes in loop size due to influence of geothermal gradient

\begin{tabular}{|c|c|c|c|c|c|c|}
\hline $\begin{array}{c}\text { Borehole } \\
\text { spacing } \\
\text { distance, } \mathrm{m}\end{array}$ & $\begin{array}{l}\text { Loop size } \\
\text { (Gradient } \\
\text { excluded } \\
13,1^{\circ} \mathrm{C} \text { ), m }\end{array}$ & $\begin{array}{l}\text { Loop size } \\
\text { (Gradient } \\
\text { included), m }\end{array}$ & $\begin{array}{l}\text { Change in } \\
\text { loop size, \% }\end{array}$ & $\begin{array}{l}\text { Depth per } \\
\text { bore, m }\end{array}$ & $\begin{array}{l}\text { Effective ground } \\
\text { temperature with } \\
\text { gradient included, } \\
{ }^{\circ} \mathrm{C} \\
\end{array}$ & $\begin{array}{c}\text { Ground } \\
\text { temperature } \\
\text { difference, } \\
{ }^{\circ} \mathrm{C} \\
\end{array}$ \\
\hline \multicolumn{7}{|c|}{ 5x4 Borehole Array Grid } \\
\hline 4,0 & 2460,9 & 2286,3 & 7,1 & 114,3 & 14,15 & 1,05 \\
\hline 5,0 & 2301,8 & 2163,1 & 6,0 & 108,2 & 13,99 & 0,89 \\
\hline 6,0 & 2186,1 & 2069,5 & 5,3 & 103,5 & 13,89 & 0,79 \\
\hline 7,0 & 2107,7 & 2005,7 & 4,8 & 100,3 & 13,82 & 0,72 \\
\hline 8,0 & 2050,9 & 1954,7 & 4,7 & 97,7 & 13,73 & 0,63 \\
\hline \multicolumn{7}{|c|}{ 10x2 Borehole Array Grid } \\
\hline 4,0 & 2279,9 & 2141,4 & 6,1 & 107,2 & 13,97 & 0,87 \\
\hline 5,0 & 2175,1 & 2060,4 & 5,3 & 103,0 & 13,89 & 0,79 \\
\hline 6,0 & 2103,7 & 2001,8 & 4,8 & 100,1 & 13,81 & 0,71 \\
\hline 7,0 & 2053,8 & 1957,2 & 4,7 & 97,9 & 13,78 & 0,68 \\
\hline 8,0 & 2014,2 & 1927,5 & 4,3 & 96,4 & 13,73 & 0,63 \\
\hline
\end{tabular}

On Fig.5. results of long-term ground loop operation simulation are presented. It can be seen that if loop is sized for 30 years of operation, first years of operation would be most efficient for the geothermal system, as it benefits from 'oversized' loop. After 30 years some indication of steady state appearance can be noticed in loop solution temperatures. 


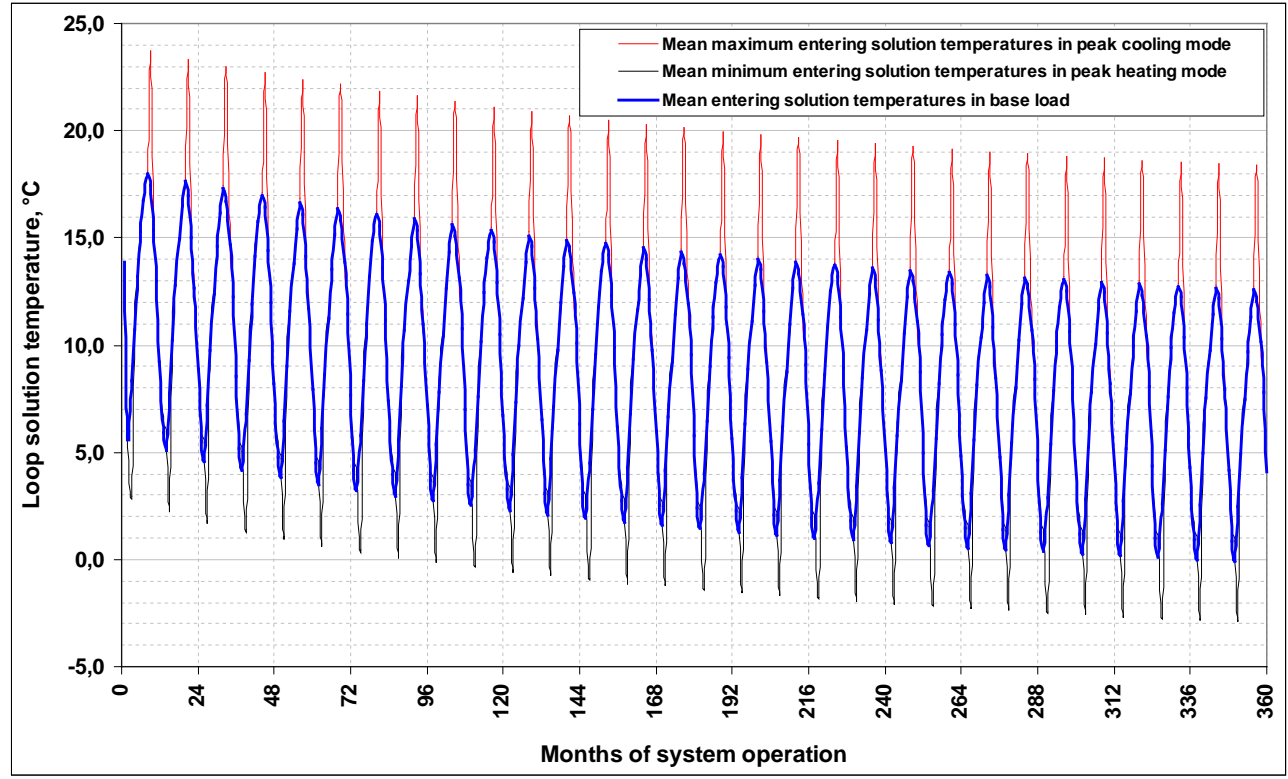

Fig.5. Changes in loop solution temperatures for 30 years of operation for array grid $5 \times 4$ and included geothermal gradients, with input data seen in Tables 1 to 4.

\section{Conclusion}

Analysis of geothermal gradient influence on borehole heat exchanger system showed that for regions where gradients are significantly higher than average, as it is case for northern part of Republic of Croatia, special care should be taken when defining parameters for simulation software input file. As seen from presented results in Fig.4 and Table 4. if only undisturbed ground temperature is entered, which in case of Zagreb location is equal to $13,1^{\circ} \mathrm{C}$, and not effective ground temperature that for same location, in $5 \times 4$ array grid with $6,0 \mathrm{~m}$ bores spacing distance and $103,5 \mathrm{~m}$ per bore depth, is equal to $13,9^{\circ} \mathrm{C}$ loop length differs $5,3 \%$. Therefore, this percentage could not be neglected in pre-feasibility project analysis.

\section{References}

[1] Carslaw, H. S.; Jaeger J. C. 1946. Conduction of Heat in Solids, Oxford,Claremore Press.

[2] Ingersoll, L.R.; Zobel, O.J.; Ingersoll, A.C. 1954. Heat Conduction with Engineering, Geological and Other Applications. Madison, WI: The University of Wisconsin Press.

[3] Kavanaugh, S.P.; Rafferty, K. 1997. Ground-source Heat Pumps: Design of Geothermal Systems for Commercial and Institutional Buildings. American Society of Heating, Refrigeration and Airconditioning Engineers, Inc., Atlanta, GA.

[4] Eskilson, P. 1987. Thermal Analysis of Heat Extraction Boreholes. Doctoral Thesis, University of Lund, Department of Mathematical Physics. Lund, Sweden.

[5] Kurevija, T.; Vulin, D. 2010. Determining Of Undisturbed Ground Temperature As The Part Of Shallow Geothermal Resources Assessment, The Mining-Geological-Petroleum Bulletin, Faculty of Mining, Geology and Petroleum Engineering, Vol.22, p.27-36

[6] Soldo, V.; Rusevljan, M.; Curko, T.; Grozdek, M. 2010. Ground-source heat pump with a $100 \mathrm{~m}$ deep borehole heat exchanger - start up and first results, IIR/Eurotherm Sustainable Refrigeration and Heat Pump Technology Conference, Stockholm 